\title{
Boom turystyczny w Islandii - wyzwania zrównoważonego rozwoju
}

\author{
Agnieszka Bołdak ${ }^{1 *}$, Agata Stefanowska ${ }^{1}$, Michał Niwiński $^{2}$ \\ ${ }^{1}$ Akademia Wychowania Fizycznego Józefa Piłsudskiego w Warszawie, Wydział Turystyki i Rekreacji \\ ${ }^{2}$ Szkoła Główna Handlowa w Warszawie, Kolegium Ekonomiczno-Społeczne \\ *agnieszka.boldak@gmail.com
}

\section{Streszczenie}

Islandia jako wyspa wyjątkowa zarówno pod względem walorów przyrodniczych jak i kulturowych, stwarza doskonałe warunki do uprawiania różnych form turystyki i rekreacji nastawionych na kontakt z naturą. Obecnie turystyka stała się jedną z dominujących gałęzi gospodarki tego kraju. Gwałtowny rozwój turystyki powoduje proporcjonalny wzrost oddziaływania na zasoby naturalne Islandii. W odniesieniu do wielkości wyspy i jej położenia na obszarach arktycznych, nawet niewielki ruch turystyczny powoduje zmiany w środowisku naturalnym. Władze Islandii dostrzegają wyzwania, jakie stoją przed nimi w kontekście dalszego rozwoju branży turystycznej i podejmują działania mające na celu zrównoważony rozwój tego obszaru. Celem niniejszego artykułu jest analiza wpływu rozwoju turystycznego Islandii na walory przyrodnicze wyspy w odniesieniu idei zrównoważonego rozwoju.

\section{Slowa kluczowe}

turystyka, Islandia, rozwój zrównoważony

\section{Wprowadzenie}

Branża turystyczna jest coraz ważniejszą i stale rozwijającą się gałęzią gospodarki. Zjawisko to niewątpliwie wpływa na środowisko naturalne, warunki ekonomiczne oraz społeczności lokalne, a więc na te sfery, na których koncentruje się rozwój zrównoważony (Para 2013: 6).

Koncepcja zrównoważonego rozwoju w turystyce polega na tym, aby turystyka stała się na dłuższą metę ekonomicznie opłacalna (także dla społeczności przyjmującej), ekologicznie neutralna i społecznie sprawiedliwa. Te trzy składowe łączą w jedną, spójną całość gospodarkę turystyczną, uczestników turystyki, czyli turystów i społeczność przyjmującą turystów, oraz miejsca docelowe, do których udają się turyści. Wszystkie te elementy powinny być traktowane równoważnie, gdyż jedynie ich rozsądne połączenie ma szansę zaowocować powstaniem i rozwojem zrównoważonej turystyki (Kazimierczak 2010: 12).

Koncepcja zrównoważonej turystyki została szczegółowo zdefiniowana przez Federację Parków Narodowych i Rezerwatów Przyrody Europy jako „każda forma rozwoju turystycznego, zarządzania i aktywności turystycznej, która podtrzymuje ekologiczną, społeczną i ekonomiczną integralność terenów, a także zachowuje w niezmienionym stanie zasoby naturalne i kulturowe tych obszarów" (Zaręba 2008: 37). Światowa Organizacja Turystyki UNWTO rozumie turystykę zrównoważoną jako właściwą koncepcję rozwoju przemysłu turystycznego 
w skali globalnej, która odnosi się zarówno do masowych, jak i niszowych form turystyki oraz do wszystkich miejsc penetracji turystycznej na świecie (Zaręba 2008: 37). Żadna tradycyjna forma turystyki, również masowa, nie powinna być z góry uznana za "niezrównoważoną" formę turystyki, a z drugiej strony nie ma takiej formy turystyki, którą można by uznać za synonim zrównoważonej turystyki. Należy raczej skupić się na przydatności różnych form turystyki do realizacji idei równoważenia sektora (Dobrzański et al. 2010: 153).

W proces rozwoju miejsc penetracji turystycznej może być zaangażowanych szereg podmiotów, wśród których wyróżniamy: podmioty gospodarcze, społeczności lokalne, środowiska odpowiedzialne za ochronę przyrody i kultury, jednostki samorządu terytorialnego, społeczne organizacje turystyczne, środowiska naukowe, turystów, lokalne jednostki Narodowej Administracji Turystycznej (NTA) oraz Narodowej Organizacji Turystycznej (NTO) (Szczechowicz 2010: 169). Każda z grup interesu biorąca udział w procesie kształtowania turystyki na obszarze chronionym przypisuje rozwojowi turystyki cel nadrzędny, najbardziej korzystny z jej punktu widzenia (Dzwonkowska 2011: 36-39; Gałązka 2013: 150-151). Według Szczechowicza (2010: 169) podstawowe znaczenie dla rozwoju zrównoważonego regionów turystycznych mają trzy pierwsze z wymienionych grup interesów ich decyzje bowiem w sposób bezpośredni kształtują podażową stronę rynku turystycznego. Gałązka (2013:150) z kolei stwierdza, że szanse powodzenia we wprowadzaniu założeń turystyki zrównoważonej na danym obszarze zależą przede wszystkim od postaw oraz motywacji samej społeczności lokalnej, która powinna angażować się w podejmowane działania, a co więcej, powinna być świadoma korzyści z rozwoju turystyki na danym terenie (Gałązka 2010: 39-40). Społeczności lokalnej przyświecają dwa cele, będące jednak ze sobą w sprzeczności: przyciągnięcie jak największej liczby turystów, którzy dostarczają przychodów, oraz zachowanie walorów obszaru w jak najmniej zmienionym stanie, aby mogły nadal przyciągać turystów (Dzwonkowska 2011: 39-4O; Ganowicz-Bączyk 2013: 44-45).

Zachowanie walorów przyrodniczych i dbałość o ochronę środowiska powodują wzrost atrakcyjności oferty turystycznej i przyciągnięcie większej liczy turystów. Turyści charakteryzują się coraz większą świadomością ekologiczną, popularność zyskuje trend prowadzenia życia przyjaznego środowisku. Konsumenci produktów turystycznych coraz częściej korzystają z oferty przedsiębiorstw, które kierują się zasadami zrównoważonego rozwoju (Para 2013: 11-12). Z zasobów przyrodniczych korzysta przede wszystkim turystyka wiejska, agroturystyka i ekoturystyka. Zasoby przyrodnicze stanowią również bazę dla różnych form turystyki, zwłaszcza turystyki kwalifikowanej, krajoznawczej, aktywnej rekreacji, czy wreszcie sportów ekstremalnych. Aktualne główne trendy światowej turystyki, prognozowane do roku 2020, wskazują, że turyści większość swojej aktywności będą przeznaczali na kontakt z przyrodą, szukając przy tym terenów dotychczas jeszcze nieeksplorowanych masowo. Nastąpi więc skupienie uwagi na obszarach szczególnie cennych przyrodniczo, niejednokrotnie wymagających od turysty odpowiedniego przygotowania sprzętowego jak też specjalnych umiejętności (Stokłosa, Krupa 2013: 19; Durydiwka, Kowalczyk, Kulczyk 2010: 34). Celem niniejszego artykułu jest analiza wpływu rozwoju turystycznego Islandii na walory przyrodnicze wyspy wobec idei zrównoważonego rozwoju.

\section{Islandia - specyfika rozwoju turystycznego}

Trendy omówione powyżej wskazują na ogromną szansę dla rozwoju Islandii jako atrakcyjnej i popularnej destynacji turystycznej. Islandia, wyjątkowa pod względem klimatu, przyrody i krajobrazów stwarza doskonałe warunki do uprawiania różnych form turystyki i rekreacji nastawionych na kontakt z przyrodą. 
W ciągu ostatnich 20 lat można zaobserwować bardzo szybki rozwój przemysłu turystycznego Islandii, co potwierdza fakt, że w tym czasie turystyka Islandii rozwijała się szybciej niż światowa turystyka (The Boston Consulting Group 2013: 11).

Wstępne dane przedstawione przez islandzki urząd statystyczny w 2016 r. wskazują, że realny PKB tego kraju wzrósł o 7,2\%. Tylko w czwartym kwartale niewyrównany sezonowo wzrost wynosił aż $11,3 \%$. Oba wyniki są najwyższe od $2007 \mathrm{r}$. Wskazuje to, że Islandia notuje najszybszy wzrost PKB wśród wszystkich państw rozwiniętych (tzn. członków OECD) (Web- o1). Turystyka stała się najbardziej dochodową gałęzią islandzkiej gospodarki, obecnie jest ona bardziej dochodowa niż przemysł rybny, czy produkcja aluminium. Znaczenie turystyki potwierdza m.in. liczba osób zatrudnionych w szeroko pojętym przemyśle turystycznym, która wzrosła w latach 2010-2014 aż o 37,6\%. W XXI wieku zaobserwować można również ogromny wzrost liczby turystów zagranicznych odwiedzających Islandię (średnio o 9,3\% rocznie), w sumie w 2014 roku liczba turystów zagranicznych była trzykrotnie wyższa niż w roku 200o. W latach 20102014 przychody od turystów zagranicznych wzrastały rokrocznie średnio o 20\% (Óladóttir 2015: 2-4). W 2016 r. ich liczba wyniosła 1,8 mln wobec $1,3 \mathrm{mln}$ w 2015 r. i 4,64 tys. w 2009 r. Ogromny wzrost liczby turystów w pierwszych dwóch miesiącach tego roku (59\% więcej niż przed rokiem) pozwala sądzić, że w 2017 r. łączny wynik znacznie przekroczy 2 mln, a zyski z tego sektora za 2017 r. mają, według prognoz, wynieść 5,1 mld dol. (Web-o1).

Biorąc pod uwagę sezonowość turystyki, ruch turystyczny dominuje w miesiącach letnich, przede wszystkim w lipcu i sierpniu. Warto jednak odnotować, że w ciągu ostatnich lat zaobserwowano istotny wzrost liczby turystów w miesiącach zimowych. Przykładowo, w 2014 roku, w lecie Islandię odwiedziło 42,2\% wszystkich turystów, zimą $28,9 \%$, natomiast jesienią $16 \%$, a wiosną tylko 13\% (Óladóttir 2015: 7). Zwiększony ruch turystyczny w miesiącach zimowych jest najprawdopodobniej związany ze wzrostem popularności wyjazdów krótkookresowych, który przypada właśnie na tą porę roku (PKF 2013: 10).

Ruch turystyczny Islandii jest zróżnicowany nie tylko pod względem pory roku, ale również regionów wyspy. Popularność poszczególnych regionów Islandii można określić na podstawie analizy obłożenia bazy noclegowej. Najbardziej popularnym obszarem Islandii jest Reykjavik i jego najbliższa okolica, tu odbyło się ponad 46\% wszystkich noclegów w 2014 roku. Pozostałe noclegi odbyły się w innych częściach Islandii, gdzie do bardziej atrakcyjnych obszarów należało południe wyspy, potem północ, następnie wschód, najmniej noclegów stwierdzono na północnym-zachodzie wyspy (Óladóttir 2015:11-12). Należy jednak podkreślić, że wzrost liczby turystów obserwuje się we wszystkich regionach kraju, choć w regionie stolicy jest on najszybszy (PKF 2013: 7).

Według badań Islandzkiej Organizacji Turystycznej, wśród turystów zagranicznych nieznacznie dominują kobiety, średnia wieku to około 40 lat, z wysokim lub średnim dochodem w rodzinie. Są to przede wszystkim przyjezdni z Wielskiej Brytanii i USA, a następnie z Niemiec, Francji i Norwegii. Jeśli chodzi o turystów z Polski, w 2014 na lotnisku Keflavik wylądowało ich 19,315 tysięcy (Óladóttir 2015:10-16). Dla ponad 80\% odwiedzających głównym powodem przyjazdu są wakacje, a wybór destynacji często wiąże się ze środowiskiem naturalnym wyspy, dlatego też turyści często wybierają aktywności rekreacyjne związane z przyrodą i wysoko je cenią.

Dlaczego Islandia wydaje się być ciekawym regionem z punktu widzenia rozwoju zrównoważonego? Populacja Islandii wynosi niecałe 340 tys. mieszkańców, a liczba turystów, jaka odwiedza kraj, sukcesywnie się zwiększa. Wyspa zaczęła kilka lat temu stawać się gorącym punktem na turystycznej mapie świata, co miało związek m.in. z osłabieniem lokalnej waluty, czy promocją Islandii za pośrednictwem serialu Gra o Tron, 
którego część odcinków została nakręcona właśnie tam.

Niewątpliwie główny i podstawowy walor turystyczny Islandii stanowi jej czysta, surowa i nieskażona natura. Nazywana przez wielu Krainą Lodu i Ognia przyciąga tych, którzy szukają czystego powietrza, wolnej przestrzeni czy zapierających dech w piersiach krajobrazów. Turyści, jako główny powód przyjazdu do Islandii, wskazują właśnie naturę. Wśród elementów przyrody szczególnie atrakcyjnych, ankietowani wymienili: dzikość przyrody i krajobrazu, unikalność przyrody, a w dalszej kolejności m.in. występowanie wulkanów, występowanie lodowców, gorących źródeł, czy wodospadów. Co więcej, natura została uznana za najmocniejszą stronę Islandii jako destynacji turystycznej (62,7\% badanych) (Óladóttir 2015: 15-16). Znaczenie środowiska naturalnego potwierdzają wyniki badań przeprowadzonych wśród touroperatorów organizujących wyjazdy na Islandię. Dla wszystkich badanych przedsiębiorstw, główną atrakcją Islandii, a tym samym głównym produktem turystycznym jest właśnie natura, a także pojęcia pokrewne, takie jak geologia, wulkany, dzika przyroda. Dodatkowo, jako atrybut Islandii wskazano stosunkowo nieduży obszar, na którym można doświadczyć tak zróżnicowanego krajobrazu i przyrody (PKF 2013:17).

Wśród różnych form turystyki aktywnej turyści najczęściej wymieniają: kąpiele w basenach lub naturalnych kąpieliskach geotermalnych, oglacdanie zorzy polarnej, wyprawy na lodowiec (m.in. organizowane na skuterach śnieżnych), wycieczki statkiem (m.in. w celu obserwacji wielorybów), wycieczki i trekking na koniach, wycieczki i trekking po górach (Tabela 1). Według badań przeprowadzonych przez PKF (2013: 19) na uwagę zasługuje również obserwacja ptaków, czy wędkarstwo/ myślistwo.

Islandia to kraina wyjątkowa, zarówno z punktu widzenia historycznego, przyrodniczego czy socjologicznego. Wszystkie te elementy sprawiają, że wyspa ta, mimo że nie rozpieszcza klimatem i należy do najdroższych na świecie, jest coraz chętniej i częściej wybieranym miejscem wyjazdów turystycznych. Wydaje się, że to niezwykłe walory przyrodnicze, jak góry, wulkany, lodowce, wodospady czy jaskinie, przyciągają najwięcej odwiedzających - w dużej mierze entuzjastów mocnych wrażeń, dla których Islandia jest prawdziwym rajem.

Szlaki turystyczne dla różnych jej form można znaleźć we wszystkich częściach kraju. Krajobraz jest niezwykle zróżnicowany, o dużych powierzchniach pokrytych kolorowymi górami, polami lawy, lodowcami, gorącymi źródłami czy pustyniami czarnego piasku. Z pewnością do podstawowych form turystyki aktywnej uprawianej na Islandii należą piesze wędrówki i trekking, które są od dawna popularnym zajęciem zarówno wśród mieszkańców jak i osób odwiedzających wyspę (Mason 2007). W niezwykle bogatej ofercie znajdują się zarówno trasy jedno- jak i kilkudniowe, a wśród nich światowej sławy 53 - kilometrowy szlak Laugavegur prowadzący w pobliżu wulkanu Eyjafjallajökull (znanego z erupcji w 2010 r.), lodowca, pól lawowych i źródeł termalnych. Jest on uważany za jedną z najbardziej spektakularnych tras turystycznych na świecie.

Ogromną atrakcją turystyczną Islandii i wyjątkowym przeżyciem jest wspinaczka i trekking po jednym z kilku lodowców. Najbardziej popularną destynacją jest największy w Europie lodowiec Vatnajökull, położony na wschodzie wyspy. Większość wypraw realizowanych jest w formie jednodniowej, gdzie po krótkiej odprawie i wprowadzeniu rozpoczyna się kilkugodzinny spacer po lodowcu, podczas którego turyści poznają niepowtarzalny krajobraz i formacje lodowca, szczeliny, grzbiety czy wodospady. Dla osób szukających nieco mocniejszych wrażeń dostępne również wyprawy na skuterach śnieżnych, quadach, w psich zaprzęgach, czy na nartach ciągniętych przez motorowe sanki.

Jednak lodowiec można zwiedzać również na inne sposoby. Jednym $\mathrm{z}$ nich jest pływanie kajakiem, amfibią lub łódką po lodowcowej lagunie powstałej w wyniku topnienia 
Tabela 1. Aktywności fizyczne uprawiane przez turystów, w trakcie pobytów na Islandii [w proc.]

\begin{tabular}{lcc}
\hline \multicolumn{1}{c}{ Aktywność fizyczna } & Lato & Zima \\
\hline Baseny geotermalne & 59,1 & 61,6 \\
Oglądanie zorzy polarnej & 0,5 & 42,8 \\
Wyprawa na lodowiec, wycieczka na skuterach śnieżnych & 13,7 & 17,7 \\
Kąpiel w naturalnym kąpielisku & 25,1 & 17,5 \\
Oglądanie wielorybów & 27,5 & 17,4 \\
Jazda konna & 14,2 & 10,5 \\
Trekking z przewodnikiem, wycieczka w góry & 15,3 & 9,6 \\
Inne aktywności 'przygodowe' & 6,9 & 6,6 \\
Zwiedzanie jaskiń & 4,9 & 5,0 \\
Wycieczki statkiem (poza oglądaniem wielorybów) & 16,1 & 4,7 \\
\hline
\end{tabular}

Źródło: Opracowanie własne na podstawie Óladóttir 2015: 15

lodu. Turysta ma okazję z bliska podziwiać góry lodowe płynące wolnym nurtem w kierunku morza, usłyszeć dźwięk pękającego lodowca, zobaczyć czarny pył - pozostałości po wybuchach wulkanów, znajdujących się pod powierzchnią lodowca.

Dla osób, którym oglądanie lodowca z powierzchni ziemi nie wystarczy, przygotowano możliwość zwiedzania go niejako od środka. Kolejną wyjątkową atrakcją Islandii są jaskinie lodowe, czyli podziemne korytarze położone we wnętrzu lodowca, utworzone w wyniku działania gorących źródeł. Turyści mogą cieszyć się widokiem niesamowitego niebieskiego koloru jaskiń, będącego efektem braku występowania w nich pęcherzyków powietrza, co w następstwie powoduje załamanie fal świetlnych w paśmie niebieskim i zielonym. Gdy lodowiec przesuwa się choć o milimetr, w jaskini słyszalne są odgłosy łamania się lodu.

Miłośników speleologii czeka jeszcze jedna atrakcja. Islandia jest bowiem jednym z niewielu miejsc na świecie, gdzie istnieje możliwość zwiedzania wnętrza komory wulkanicznej. Jednym z najpopularniejszych i uważanych za najbardziej spektakularny jest Thrihnukagigur (Krater Trzech Szczytów) - uśpiony wulkan, którego ostatnia erupcja miała miejsce ok. 4000 lat temu. Wyjątkowość tego miejsca polega na tym, iż komora magmowa, zwana sercem wulkanu nie została zasklepiona przez zastygającą lawę. Specjalna platforma linowa zwozi turystów wąskim tunelem do komory wulkanu, na głębokość 120 metrów.

Doskonałą alternatywą dla wycieczek pieszych czy samochodowych, jednocześnie pozwalającą na bezpośredni kontakt z dziewiczą przyrodą Islandii, są wycieczki i wyprawy na grzbiecie islandzkiego konia. Szlaki konne zlokalizowane w Islandii cieszą się światową sławą (Ollenburg 2006: 310) i dużym zainteresowaniem wśród turystów. Szacuje się, że około 15-18\% odwiedzających Islandię korzysta $\mathrm{z}$ tej formy podczas pobytu na wyspie (Helgadottir, Sigurdardottir 2008: 105,114). Koń islandzki to unikatowa rasa niewielkich, bardzo wytrzymałych koni, które pojawiły się na wyspie wraz z pierwszymi osadnikami 1100 lat temu i obecnie rasa ta jest uznawana za jedną z najczystszych i nieskażonych (koń, który raz opuścił Islandię nie może już wrócić).

Choć mogłoby się wydawać inaczej, również zimne wody Islandii stanowią atrakcyjne miejsce do uprawiania sportów wodnych, zwłaszcza nurkowania. Dzieje się to głównie za sprawą niebywałej czystości i przejrzystości wody, a także wyjątkowości wyspy pod względem geologicznym oraz przyrodniczym. Islandia jest jedynym wypiętrzonym ponad powierzchnię oceanu fragmentem Grzbietu Środkowoatlantyckiego, który stanowi granicę między płytami kontynentalnymi. I to właśnie Silfra, czyli szczelina między eurazjatycką i północnoamerykańską płytą tektoniczną, uznawana 
jest za jedno z najciekawszych miejsc nurkowych na świecie. Woda wypełniająca szczelinę należy do najczystszych wód naturalnych na naszej planecie, a średnia widzialność wynosi $100 \mathrm{~m}$. Mimo, że woda ma stałą temperaturę $2-4^{\circ} \mathrm{C}$, chętnych do nurkowania w krystalicznej wodzie, na głębokość kilkudziesięciu metrów między skalnymi ścianami Europy i Ameryki nie brakuje.

$\mathrm{Ci}$, którzy wolą nie zanurzać się bezpośrednio w wodach oceanu mogą wybrać się na kilkugodzinny rejs, podczas którego mogą obserwować żyjące w naturalnym środowisku różne gatunki wielorybów, fok (Granquist, Nilsson 2016), delfinów czy symbol Islandii - maskonura (Becker 2011). Dla bardziej żądnych wrażeń przygotowane są wyprawy łodzią poza koło podbiegunowe.

Zwieńczeniem dnia wypełnionego aktywnością może być kąpiel w jednym z gorących basenów lub kąpielisk termalnych na świeżym powietrzu, gęsto rozsianych na terenie całej wyspy, bardzo popularnych również wśród mieszkańców. Wśród nich znajdziemy zarówno te naturalne, bezpośrednio zasilane podziemnymi źródłami, pachnące siarką i bogate w minerały oraz sztuczne - często pięknie położone, jedynie podgrzewane energią termalną. Woda ma zwykle temperaturę $38-42^{\circ} \mathrm{C}$, co pozwala na przyjemny relaks i odprężenie nawet, gdy temperatura powietrza oscyluje w okolicach zera (Bołdak et. al. 2016: 9-12).

\section{Wyzwania zrównoważonego rozwoju turystyki}

Lokalne władze Islandii dostrzegają zagrożenia związane z gwałtownym napływem turystów. „(...) niektóre miejsca zwyczajnie nie są w stanie pomieścić miliona turystów każdego roku. Jeśli zaczniemy wpuszczać do tych miejsc więcej ludzi, stracą one to, co czyni je wyjątkowymi" - powiedziała cytowana przez Bloomberga Thordis Kolbrun Reykfjord Gylfadottir, islandzka minister turystyki. Jej zdaniem, zarówno krajowy sektor turystyki, jak i sami Islandczycy „muszą uważać, by nie paść ofiarami własnego sukcesu" (Web-o2).
Rozwój turystyki powoduje proporcjonalny wzrost odziaływania na zasoby naturalne Islandii. Istotne jest jednak, że na obszarach arktycznych, do których zalicza się wyspa, nawet niewielki ruch turystyczny powoduje zmiany w środowisku naturalnym. Rozwój form turystyki, takich jak turystyka piesza, czy tych bardziej alternatywnych (jazda na rowerach, skuterach śnieżnych, maratony) może powodować obniżenie wartości wizualnej obszarów oraz erozję gleby, która dotyka często nie tylko szlaków, ale większych obszarów.

Zwiększony ruch turystyczny ma wpływ również na faunę obszaru, może oddziaływać negatywnie zarówno na jednostki, jak również całe populacje organizmów. Jedną z popularnych form turystyki przyrodniczej (wildlife tourism) na Islandii jest obserwacja zwierząt morskich: wielorybów, delfinów, fok. Granquist i Sigurjonsdottir (2014: 85-93) na przykład badały wpływ turystów na foki, w trakcie ich obserwacji. Badania wykazały, że im większy liczba turystów, tym wyższe prawdopodobieństwo wystąpienia wzmożonej czujności zwierząt, zwłaszcza przy aktywnym, a nie biernym zachowaniu turystów. Co więcej, im więcej turystów, tym zwierzęta przebywają w większej odległości od lądu.

Rosnąca liczba turystów może mieć negatywny wpływ zarówno na środowisko przyrodnicze, czy społeczne obszaru jak również na sposób postrzegania miejsca przez samych turystów. Według badań Sæpórsdóttir (2013: 47-58) przeprowadzonych w latach 2000 i 2009 wśród turystów w Landmannalaugar (na „wyżynach” - Highlands), zbyt duża liczba turystów staje się coraz bardziej odczuwalna przez nich samych (w 2000 roku $22 \%$ respondentów uznało ich liczbę za zbyt wysoką, w $2009-32 \%$ ), co jest dla odwiedzających czynnikiem powodującym rozczarowanie (12\% w 20 ooroku i aż $28 \%$ w 2009). Nie tylko wzrasta liczba turystów, ale również zmienia się ich stosunek do natury, który staje się coraz mniej purystyczny, a coraz bardziej antropocentryczny. 
Władze Islandii dostrzegają wyzwania, jakie stoją przed nimi w kontekście dalszego rozwoju branży turystycznej. Agencja środowiska Islandii stworzyła czerwoną listę obszarów chronionych, które wymagają natychmiastowych działań w celu zachowania walorów naturalnych. Rejon Landmannalaugar jest jednym z trzech obszarów na szczycie tej listy (Sæpórsdóttir 2013: 56). Aby zapobiec degradacji naturalnego piękna wyspy prowadzonych jest szereg badań, jak też praktycznych inicjatyw i akcji edukacyjnych skierowanych zarówno do społeczności lokalnej jak i turystów.

Granquist i Nilsson (2016: 471-478) jako sposób na zminimalizowanie negatywnego wpływu turystyki, wskazują na kontrolę liczby odwiedzających na szlakach, zwłaszcza na obszarach szczególnie wrażliwych, minimalizowanie wielkości grup turystycznych, a także szkolenie turystów w zakresie spokojnego i cichego zachowania w trakcie obserwacji zwierząt. Zdaniem autorów ta metoda umożliwiłaby zwiększenie akceptowalnej liczby turystów w destynacji turystycznej. Wskazują również na konieczność zwiększenia świadomości i zmiany postrzegania problemu przez turystów poprzez edukację, przy wykorzystaniu odpowiedniego kodeksu postępowania. Turyści zazwyczaj chcą zachowywać się odpowiednio, tak aby w minimalnym stopniu powodować degradację środowiska, jednak brak im odpowiedniej wiedzy w tym zakresie. Dodatkowo, turyści powinni zostać objęci określonym zbiorem zasad zachowania, lub być edukowani w zakresie wrażliwości ekologicznej obszaru i wpływu ich działalności na ekosystem. Kluczowa jest również jakość szlaków, ich oznakowanie itp., które nie powinno skłaniać turystów do zbaczania ze szlaku (Ólafsdóttir, Runnström 2013: 6566). W ostatnim czasie pojawiły się anglojęzyczne przewodniki, w których zwrócono uwagę na pożądane zachowania turystów w kontekście poszanowania dla środowiska naturalnego. Duża część atrakcji dostępna jest zwiedzającym wyłącznie pod opieką przeszkolonego przewodnika.
Sæpórsdóttir (2013: 47-58) zwraca uwagę, że w zaistniałej sytuacji, aby zachować walory naturalne i dzikość szlaków pasma wyżyn (Landmannalaugar), które są jego największą atrakcją, niezbędne jest zrównoważone zarządzanie. Występują jednak sprzeczne opinie na temat dalszego rozwoju turystyki na tym obszarze, dotyczące m.in. zwiększenia dostępności obszaru (budowy dróg asfaltowych). Jednym z pomysłów na regulację ruchu turystycznego jest zamknięcie sklepów na tym obszarze, co zmusiłoby turystów do skrócenia swojego pobytu i przeniesienia się na niziny w celu zrobienia zakupów. Drugą opcją jest wprowadzenie opłat za wstęp, choć obecnie odwiedzanie naturalnych atrakcji Islandii jest bezpłatne.

Na skutek stosunkowo ubogiej bazy noclegowej, dość wysokich cen oraz braku wyraźnych zakazów kempingowania poza wyznaczonymi do tego obszarami, w ostatnich latach nastąpił znaczący wzrost popularności podróżowania po Islandii samochodami kempingowymi, lub rozbijania namiotów w pobliżu trasy. Doprowadziło to do sytuacji, w których podróżni rozbijali dziesiątki namiotów w parkach publicznych i innych tego typu miejscach. W odpowiedzi na skargi lokalnej ludności odnośnie zaśmiecania i zanieczyszczania dzikich obozowisk, a także w trosce o ochronę przyrody wprowadzono regulację prawną zakazującą obozowania poza miejscami specjalnie do tego wyznaczonymi (Web-o3).

Innym sposobem na regulację napływu turystów może stać się opodatkowanie branży turystycznej. Rząd Islandii bierze pod uwagę nałożenie dodatkowych kosztów na przewoźników oraz obiekty noclegowe. Z pewnością znacząco podniosłoby to ceny usług na Islandii, która i tak już zaliczana jest do najdroższych krajów na świecie (Web-02).

\section{Zakończenie}

Nie ulega wątpliwości, że Islandia stanowi absolutnie unikatową na skalę światową destynację turystyczną. Jest krainą wyjątkową zarówno z punktu widzenia przyrodniczego, historycznego czy socjologicznego. Mimo 
surowości klimatu i krajobrazu oraz niemal najwyższych cen na świecie jest coraz częściej i chętniej wybieranym miejscem wyjazdów turystycznych. Najwięcej odwiedzających przyciągają zapierające dech w piersiach krajobrazy lodowców, wulkanów, wodospadów czy jaskiń. Niestety te niezwykłe formy kształtowane przez naturę tysiące lat, mogą bardzo szybko ulec nieodwracalnej degradacji w wyniku zbyt dużej presji turystycznej.

Turystyka na Islandii stała się dominującą gałęzią gospodarki, więc wydaje się oczywistym, że są niewielkie szanse, aby beneficjenci tego trendu zdecydowali się nagle zamknąć kraj dla zwiedzających lub znacząco utrudnić do niego dostęp, zwłaszcza że to m.in. polityka proturystyczna (np. budowa portu lotniczego Keflavik) umożliwiła Islandii szybkie wyjście z kryzysu gospodarczego 2008 r. Niezbędna jest długofalowa i przemyślana strategia, która pozwoli na ochronę cennych walorów przyrodniczych, godząc interesy pozostałych interesariuszy społeczności lokalnych, sprzedawców usług turystycznych oraz samych turystów. Zadanie to jest bez wątpienia niezwykle trudne i ambitne, jednak trzeba mieć nadzieję, że Islandczycy, naród który wielokrotnie został ciężko doświadczony przez los, jednocześnie bardzo dumny ze swojej przyrody i świadomy ekologicznie znajdzie rozwiązania, które umożliwią turystom podziwianie unikalnych walorów przyrodniczych przy jednoczesnym poszanowaniu natury i lokalnych społeczności.

\section{Bibliografia}

Bołdak A., Stefanowska A. Niwiński M., 2016, Turystyka aktywna jako czynnik rozwoju turystyki, na przyktadzie Islandii, Turystyka i Rekreacja, vol. 13, 6-16.

Dobrzański G., Borkowska-Niszczota M., Kiryluk H., Szymańska E., 2010, Problemy interpretacji turystyki zrównoważonej, Folia Turistica, Turystyka i ekologia, Kraków, vol. 22, 147-166.

Durydiwka M., Kowalczyk A., Kulczyk S., 2010, Definicja i zakres pojęcia „turystyka zrównoważona”, w: Kowalczyk A. (red.), „Turystyka zrównoważona”, PWN, Warszawa, 21-43.

Dzwonkowska D., 2011, Zasada zrównoważonego rozwoju w turystyce, Studia Ecologiae et Bioethicae, vol. 9, 23-41.

Gałązka M. 2013, Społeczne uwarunkowania turystyki zrównoważonej w gminie Stare Babice, Zeszyty Naukowe „Turystyka i Rekreacja”, Warszawa, vol. 12(2), 149-168.

Ganowicz-Bączyk A., 2013, Ekonomia w stużbie zrównoważonego rozwoju, Studia Ecologiae et Bioethicae, vol. 1, 29-45.

Granquist S.M., Nilsson P.-Å., 2016, Who's watching whom? e an interdisciplinary approach to the study of seal-watching tourism in Iceland, Journal of Cleaner Production, vol. 111, 471-478.

Granquist S.M., Sigurjonsdottir H., 2014, The effect of land based seal watching tourism on the haul-out behaviour ofharbour seals (Phoca vitulina) in Iceland, Applied Animal Behaviour Science, vol. 156, 85-93.

Kazimierczak M., 2010, Jaka aksjologię zaktada idea zrównoważonego rozwoju w turystyce? [w]: Młynarczyk Z., Potocka I., Zajadacz A. (red.), „Uwarunkowania i plany rozwoju turystyki", Tom VI Turystyka zrównoważona, Bogucki Wydawnictwo Naukowe, Poznań, 9-18.

Óladóttir O.P., 2015, Tourism in Iceland in Figures, Icelandic Tourist Board.

Ólafsdóttir R. , Runnström M.C. , 2013, Assessing hiking trails condition in two popular tourist destinations in the Icelandic highlands, Journal of Outdoor Recreation and Tourism, vol. 3-4, 57-67.

Para A., 2013, Zasady zrównoważonego rozwoju turystyki - bariery i szanse dla branży turystycznej, Zeszyty Naukowe „Turystyka i Rekreacja”, Warszawa, vol. 11(1), 5-16.

PKF, 2013, Promote Iceland. Long-term strategy for the Icelandic tourism industry, Accountants and business advisers.

Sæbórsdóttir A.D., 2013, Managing popularity: Changes in tourist attitudes in a wilderness destination, Tourism Management Perspectives, vol. $7,47-58$.

Stokłosa Ł., Krupa J., 2013, Rozwój turystyki zrównoważonej na obszarach chronionych, Zeszyty Naukowe „Turystyka i Rekreacja”, Warszawa, vol. 11(1), 17-32. 
Szczechowicz B, 2010, Zrównoważony rozwój obszarów recepcji turystycznej-grupy interesów i źródta konfliktów, Folia Turistica, Turystyka i ekologia, Kraków, vol. 22, 167-184.

The Boston Consulting Group, 2013, Northern Sights: The future of tourism in Iceland.

Zaręba D., 2008, Ekoturystyka, PWN, Warszawa.
Witryny internetowe

web-o1 www.bankier.pl/wiadomosc/Islandia-przezywa-boom-gospodarczy-Turystyka-Polacy-i-mocniejsza-korona-7503845.html dostęp: 2.12.2017.

web-02 www.forbes.pl/wiadomosci/naplyw-turystow-do-islandii-i-plany-podniesienia-podatkow/ cbrmbry dostęp: 2.12.2017.

web-o3 http://icelandnews.is/wiadomosci/z-kraju/ nowe-zasady-dotyczace-biwakowania-w-poludniowej-islandii dostęp: 2.12.2017.

\title{
Tourist boom in Iceland - the challenges of sustainable development
}

\begin{abstract}
Iceland as an exceptional island, both in terms of natural and cultural values, creates perfect conditions for practicing various forms of tourism and recreation, focused on contact with nature. At present, tourism has become one of the the dominant branches of the country's economy. The rapid development of tourism causes a proportional increase in impact on Iceland's natural resources. In relation to the size of the island and its position [location] in the Arctic, even a small tourist traffic causes changes in the environment. The Icelandic authorities recognize the challenges they face in the context of the further development of the tourism industry and undertake activities aimed at the sustainable development of this area.

The purpose of this article is to analyze the impact of Iceland's tourist development on the natural values of the island in the light of the idea of sustainable development.
\end{abstract}

\section{Keywords}

tourism, Iceland, sustainable development 